\title{
Advancing the Debate about Heidegger's Phenomenology of Death as a Possibility
}

\author{
Eric J. Ettema1, Louise D. Derksen ${ }^{2}$, Evert van Leeuwen ${ }^{3}$ \\ ${ }^{1}$ Department of Medical Humanities, Section Philosophy and Medical Ethics, VU University Medical Center, \\ Amsterdam, The Netherlands \\ ${ }^{2}$ Department of Philosophy, Vrije Universiteit, Amsterdam, The Netherlands \\ ${ }^{3}$ Department of IQ, Section Ethics, Philosophy and History of Medicine, Radboud University of Nijmegen, \\ Nijmegen, The Netherlands \\ Email:ej.ettema@vumc.nl,I.d.derksen@vu.nl,Evert.vanleeuwen@radboudumc.nl
}

Received 15 October 2015; accepted 23 November 2015; published 27 November 2015

Copyright (C) 2015 by authors and Scientific Research Publishing Inc.

This work is licensed under the Creative Commons Attribution International License (CC BY). http://creativecommons.org/licenses/by/4.0/

(c) (i) Open Access

\begin{abstract}
Heidegger's understanding of death in terms of possibility has been debated for more than three decades. The main dispute is about the coherence of the concept of possibility. To advance the debate, we analyse the meaning of "death as a possibility" in three steps. Firstly, we delineate the notions of death and possibility in Heidegger's fundamental ontology. Secondly, we analyse and evaluate the main opposed interpretations of death as a possibility. Thirdly, we discuss Heidegger's assertion that death is a distinctive [ausgezeignete] possibility of Dasein. On the basis of the results, we claim that Heidegger provides an ontic-ontological and multilayered framework for the understanding of death. We further argue that one of those layers relates to death as a transcendent possibility for Dasein, which can be further characterised in terms of non-genuine, genuine and-what we call-deconstructive [Abbauende] authenticity. Finally, we suggest that deconstructive authenticity refers to Dasein's authentic relationship to its own ontological annihilation. As this annihilation cannot be phenomenologically depicted, deconstructive authenticity implies that Dasein is, to a certain extent, free to depict the meaning of its death.
\end{abstract}

\section{Keywords}

Heidegger, Death, Possibility, Phenomenology

\section{Introduction}

Heidegger's concept of death as a possibility is seen as one of the most profound philosophical understandings

How to cite this paper: Ettema, E. J., Derksen, L. D., \& van Leeuwen, E. (2015). Advancing the Debate about Heidegger's Phenomenology of Death as a Possibility. Open Journal of Philosophy, 5, 445-458.

http://dx.doi.org/10.4236/ojpp.2015.57051 
of death. However, it is also claimed to be among the most obscure ones. That Heidegger's conception of death that is difficult to understand becomes apparent when considering some of his assertions about death. For example, Heidegger claims that the possibility of death structures Dasein's existence in such a way that Dasein is a being-towards-death (BT: 294, our italics; SZ: 251), that death is a way to be (BT: 289, our italics; SZ: 245) and that death is the possibility of the absolute impossibility of Dasein (BT: 294, our italics; SZ: 250). ${ }^{1}$ This possibility, Heidegger further states, is not just one possibility out of many, but an ausgezeignete possibility of Dasein (e.g. BT: 305; SZ: 261).

Taking into account Heidegger's descriptions, it is not surprising that his conception of death as a possibility has led to severe criticism. Edwards argues, for example, that Heidegger flagrantly confuses different meanings of possibility and that, as a result, the assertion that Dasein is a being-towards-death "does not constitute any kind of discovery, insight or contribution” (Edwards, 1975: p. 549). On the same grounds Philipse argues that there is "no justification left for Heidegger's thesis that death is a possibility for Dasein in any profound sense" (Philipse, 1998: p. 368). Derrida, in turn, contends that Heidegger's analysis of death as the possibility of the impossibility of Dasein "is untenable and [...] cannot even claim to have any coherence or rigorous specificity" because the appearance of a "possibility as impossibility" annihilates its own possibility (Derrida, 1993: pp. 75-79).

In response to the criticisms, various authors defend the sense and coherence of Heidegger's analysis of death as a possibility. In reply to Edwards' criticism, Llewelyn argues that Heidegger's assertion that "Dasein is a being-towards-death” has a specific meaning in terms of possibility (Llewelyn, 1983). In addition, Blattner givesretrospectively - a convincing solution to Philipse's objections regarding Heidegger's claim that "the possibility of death is a way to be” (Blattner, 1994). Thomson, in his turn, presents a thoughtful correction of Derrida's analysis of Heidegger's contention that “death is the possibility of the absolute impossibility of Dasein” (Thomson, 1999). Carel, finally, rejects Edwards’ and Philipse’s interpretation and, building on Dreyfus and Blattner, claims to offer a coherent reading of Heidegger's descriptions of death as a possibility (Carel, 2007).

In this article we aim to advance the ongoing debate regarding the meaning of possibility in Heidegger's analysis of death. We will do so in three steps. Firstly, we delineate the notions of "death" and "possibility” in Heidegger's fundamental ontology. Secondly, we analyse and evaluate the meaning of death in terms of possibility by discussing the main interpretations of Heidegger's assertions that "Dasein is a being towards death"; that "death is a way to be"; and that "death is the possibility of the absolute impossibility of Dasein". Thirdly, based on the outcomes of the exploration thus far, we analyse the meaning of death as a possibility in terms of what Heidegger calls an ausgezeignete Möglichkeit of Dasein.

\section{The Possibility of Death in Heidegger's Fundamental Ontology}

\subsection{The Place of Death in Fundamental Ontology}

The context in which Heidegger analyses the phenomenon of death is given by the question of Being. According to Heidegger, traditional metaphysics has never really taken up the question of Being because it questions what reality is instead of that reality is (Mulhall, 1996: p. 6; BT: 25-7, 183; SZ: 5-8, 143). Traditional metaphysics therefore leads to what Heidegger calls ontic knowledge: the knowledge of properties of beings. By focussing on properties, traditional metaphysics overlooks the more fundamental dimension of beings, namely that objects are. Heidegger purports to lay bare this underlying structure of beings, which is the Being of beings (BT: 29; SZ: 9). The exploration of what it means to be leads to what Heidegger calls ontological knowledge: the knowledge of Being as such.

Being as such cannot be explored directly from the outside because the explorer of Being necessarily takes part in Being. Heidegger therefore focuses on the meaning of Being of the explorer, i.e. man himself, which he denotes by the term Dasein (BT: 32ff, 361; SZ: 11ff, 313). Dasein is distinguished from other entities "by the fact that, in its very Being, that Being is an issue for it” (BT: 32; SZ: 12). Dasein thus takes part in Being in such a way that it understands itself as a being that is. Dasein is therefore ontically distinct from other beings "in that it is ontologically” (BT: 32; SZ: 12).

Hence, for Heidegger, Being becomes accessible through Dasein as the entity which, in its very Being, relates

\footnotetext{
${ }^{1}$ As the text contains many references to Heidegger's Being and Time, we use an abbreviated reference style. In the text references, SZ stands for the German edition of Sein und Zeit (Heidegger, 1927a), whereas BT stands for the Macquarrie and Robinson translation "Being and Time” (Heidegger, 1927b).
} 
[verhält sich] understandingly towards itself (Heidegger, 1927c: p. 49; SZ: 52-3). ${ }^{2}$ Whereas Dasein thus occupies an ontic position as a being among other beings, "the" Being of Dasein appears to Dasein only in so far as Dasein reflects ontologically upon it. As a consequence, to explore "the" Being of Dasein, Dasein must be "interrogated ontologically", i.e. from "the structure of Being" in which Dasein exists (BT: 34-5; SZ: 13-4). This interrogation leads Dasein inevitably to the awareness that Dasein's Being is finite (Heidegger, 1929/1930a: p. 8; 1929/1930b: p. 6). Heidegger therefore asserts that understanding the ontological structure of Dasein requires an analysis of the end of Dasein's Being, which is death (BT: 276-7; SZ: 233-4).

In order to explore the meaning of death, Heidegger first distinguishes death [Tod] from perishing [verenden], demise [ableben] and dying [sterben]. Perishing is the ending of what lives. Demise is Dasein's particular way of perishing as it interprets the biological fact of its perishing. Dying is neither the biological fact of perishing, nor is it the interpretation of this fact. Instead, dying is a way to be Dasein, such that Dasein relates itself [verhält sich] to the finite structure of its own Being. Hence, dying is for Heidegger "that way of Being in which Dasein is towards its death” (BT: 291; SZ: 247). Death, finally, is the end of Dasein's Being-in-the-world, which—as such—“belongs to the potentiality-for-Being” (BT: 276-7; SZ: 234).

\subsection{The Central Notion of Possibility}

To illuminate the ontological structure of Dasein, Heidegger thus needs to explore how Dasein relates understandingly to death. ${ }^{3}$ According to Heidegger, this cannot result from experience: "by its transition to no-longerDasein [Nichtmehrdasein], it gets lifted right out of the possibility of experiencing this transition and of understanding it as something experienced" (BT: 281, 306-7; SZ: 237, 262). But neither can Dasein relate to it through the death of others. Although the other's death may affect us ontically in the form of bereavement, loss or even a change in identity, it does not affect us ontologically - that is, it does not affect us in the Being of our own Dasein (BT: 284; SZ: 240). Heidegger therefore asserts that Dasein relates understandingly to its own death not as an actuality but as a possibility - i.e. the certain possibility of death in which Dasein comes to an end (BT: 63, 284, 306; SZ: 38, 240, 262). ${ }^{4}$

The meaning of "possibility" is crucial for an adequate understanding of Heidegger's conception of death (Carel, 2007: p. 543; Thomson, 1999: p. 40 n.28; Derrida, 1993: p. 63; Edwards, 1975: p. 549; Blattner, 1994: p. 50). Heidegger stresses that the meaning of possibility should not just be understood in contrast to actuality. Instead, he depicts possibility as the quiet power [stillen Kraft] of Being, which in its favoring presides over thinking in that it enables something to unfold itself in its being (Heidegger, 1946: pp. 316-317). As Heidegger describes both Dasein and death in terms of possibility, the question is what such a description implies for the meaning of Dasein's death.

With regard to Dasein, Heidegger stresses that Dasein is "primarily Being-possible” (BT: 183; SZ: 143). He distinguishes his use of the term "possibility" from "empty logical possibility", from "modal possibility" in which something can "come to pass", and from possibility as "a liberty of indifference". ${ }^{5}$ Instead, Heidegger

\footnotetext{
${ }^{2}$ Macquarrie and Robinson often translate "sich verhalten" as "to comport itself", whereas Stambaugh translates it often as "is related to" (compare e.g. BT: 78, 305; Heidegger, 1927c: pp. 49, 241; SZ: 52-3, 261). Although this latter translation seems to be more accurate at first sight, Heidegger describes "sich verhalten" mostly in active terms, as for example in: Aus-sein verhält sich so zum Möglichkeit “daß es umsichtig von dem Möglichen wegsieht auf das Wofür-möglich” (SZ: 261). We therefore mostly follow Macquarrie and Robinson in their translation of "sich verhalten" as "to comport". In combination with "understanding”, however, as in "sich verstehend verhält”, this leads to a misleading construction of "to comport understandingly" (BT: 78). In those cases, we prefer (the active form) of Stambaugh's translation and, hence, translate "sich verstehend verhält” as "to relate understandingly" (compare: BT: 78; Heidegger, 1927c: p. 49; SZ: 52-3).

${ }^{3}$ One might suggest that the relevant question is not how Dasein relates understandingly to death but, rather, how Dasein can understand death in such a way that it illuminates the structure of Dasein's own Being. However, Heidegger's focus is not on death but on the forerunning [vorlaufen] towards death, which constitutes Dasein’s Being as finite (BT: 291, 293; SZ: 247, 249; Carel, 2006: p. 70; Dastur, 1996: p. 42; Mulhall, 1996: p. 124). It is therefore in relation to death that Dasein's character "lets itself be revealed most precisely" as "understanding” (BT: 293, 32; SZ: 248-9, 12). The point at issue is therefore not merely how Dasein understands death but, rather, how Dasein relates understandingly to death.

${ }^{4}$ Heidegger stresses that “ending” does not signify Dasein’s Being-at-an-end [Zu-Ende-sein] but Dasein’s Being-towards-the-End [Sein zum Ende]. The "ending” is therefore not the ending of Dasein itself, but a possibility of Dasein's Being (BT: 289, 305; SZ: 245, 261). Hence, when Dasein relates understandingly to death as a possibility - i.e. the possibility in which Dasein comes to an end-Dasein neither relates to its end nor to the possibility of its ending. Instead, Dasein relates to the possibility of its end as possibility, i.e. as a possibility to be. This ontological interpretation, however, does not take away that the possibility of death also relates to Dasein's end in an ontic sense. As Heidegger says: "it has nevertheless been revealed that in every case I am myself the entity which we call Dasein, and that I am so as a potentiality-for-Being for which to be this entity is an issue” (BT: 361, our italics; SZ: 313).

${ }^{5}$ Liberty of indifference refers to a random choice between options. By rejecting this meaning of possibility, Heidegger takes distance from a metaphysically free-creation as starting point for his analysis of "possibility".
} 
argues that the possibility of Dasein is an existential possibility, i.e. a way in which Dasein is. Hence, Dasein is primarily Being-possible in that it is "in every case what it can be, and in the way in which it is its possibility" (BT: 183; SZ: 143). According to Heidegger, this Being-possible is transparent [durchsichtig] to Dasein in different possible ways and degrees (BT: 183; SZ: 144).

With regard to death, Heidegger distinguishes his use of the term "possibility" from three general understandings. First, the possibility of death cannot be understood as something to be actualised, for actualisation would "annihilate the possibility of the possible by making it available" (BT: 305). Second, the possibility of death cannot be understood as something to be pondered over, for such brooding weakens the possibility of death "by calculating how we are to have it at our disposal" (BT: 305-306). Third, the possibility of death cannot be understood as something to be "expected", for expecting "is essentially a waiting [...] for actualisation", which means that the possible is drawn into the actual (BT: 306). Instead, Heidegger asserts, the possibility of death must be understood as “a way to be Dasein” (BT: 289; SZ: 245).

These preliminary remarks about Dasein and death in terms of possibility enable us to analyse and evaluate the main interpretations of three well-known assertions of Heidegger: "Dasein is a being-towards-death"; "death is a way to be”; and "death is the possibility of the absolute impossibility of Dasein”.

\section{Dasein Is a Being-Towards-Death}

\subsection{Ontic Possibilities: Capability, Absence of State and Goldon Opportunity}

Heidegger's assertion that "Dasein is a being-towards-death" is one of the most well-known expressions in $B e$ ing and Time (BT: 294; SZ: 251). Various interpreters of Heidegger claim that the assertion is meaningless because it would be based on an—often overlooked—shift in the meaning of possibility.

Edwards, for example, distinguishes at least three different meanings in Heidegger's use of “possibility”. A first meaning results from Heidegger's description of Dasein in terms of its own possibilities: "Dasein determines its own character as the kind of entity it is, and it does so in every case in terms of a possibility which it itself is and which it understands” (BT: 303-4; SZ: 259; Edwards, 1975: p. 549). To show what Heidegger means, Edwards refers to a paragraph in which Heidegger explains that "Dasein is such that in every case it [...] "knows" what it is capable of - that is, what its potentiality-for-Being is capable of" (BT: 184; SZ: 144). "Possibility" thus refers here, Edwards asserts, "to the alternatives we can choose or, more precisely, which we know ourselves to be capable of choosing” (Edwards, 1975: p. 550).

A second meaning of “possibility” results, according to Edwards, from Heidegger's specification that the possibility of death refers neither to actualisation, nor to brooding or expecting (BT: 305-306). Instead, death reveals itself as possibility when we run ahead into the possibility [vorlaufen in die Möglichkeit] of death. By "running ahead" one comes closer to death "understandingly" as it "unveils" "the nature of the possibility" as "the impossibility of any existence at all” (BT: 306-7; SZ: 262). Edwards concludes from this that possibility no longer refers to "choosing” but to "the absence of all states" (Edwards, 1975: pp. 556-558, 560).

A third meaning of "possibility” appears from Heidegger's characterisation of death as an ausgezeichnete Möglichkeit of Dasein (Edwards, 1975: p. 551; SZ: 248-51). According to Edwards, ausgezeichnete should not be translated as “distinctive”, as the M-R translation does (BT: 292-5), but as "splendid” or “distinguished possibility”. He supports his claim with the help of authors who interpret the ausgezeichnete Möglichkeit of death as "the crown of culmination of human life", "life's greatest possibility”, and “the most proper possibility of man's existence” (Edwards, 1975: p. 551). Edwards concludes that the meaning of the possibility of death has changed again, now into nothing less than a "golden opportunity” for Dasein (Edwards, 1975: p. 551).

According to Edwards, these different meanings of possibility, which are implied in the meaning of Dasein as a Being-towards-death, often remain unnoticed. Once they are revealed it is easy to see that Heidegger's analysis of death as a possibility is not "wrong” but "perverse” because his "misuse” of language "does not constitute any kind of discovery, insight or contribution” (Edwards, 1975: pp. 549, 560, 562).

\subsection{Ontological Possibility: Authentic Being towards Death}

Edwards’ critique has been put aside as “difficult to defend” (Blattner, 1994: p. 69), “groundless” (Carel, 2007: p. 543), “dated” (Halteman, 2007: p. 311) and even as “ridiculously uninformed” (Thomson, 1999: p. 38 n7). These criticisms, however, are not accompanied by a thorough argumentation. Llewelyn is one of the few interpreters who not only criticises Edwards but also takes up the challenge to explore whether Edwards, in some 
way, has a point.

Llewelyn focuses his critique on Edwards' second meaning of possibility in which death is "the absence of all states" (Llewelyn, 1983: pp. 127-128). Llewelyn argues that "absence of all states" must be understood in two ways: as a possibility that death has and as a possibility that death is (Llewelyn, 1983: p. 129). Edwards follows the line of thinking that death can happen at any time and, hence, that "the absence of all states" is a possibility that death has. Llewelyn, on the other hand, stresses that "the absence of all states" is also a possibility that death is, in the sense that death is an ontological structure of Dasein in which Dasein can understand its own Being (Llewelyn, 1983: pp. 132-133). According to Llewelyn, Edwards fails to see that Heidegger discusses "the possibility that death has" within the larger context of "the possibility that death is" (Llewelyn, 1983: p. 129).

Although Llewelyn criticises Edwards for not being open to the ontological meaning of Heidegger's conception of death, he admits that he shares one difficulty with Edwards (Llewelyn, 1983: p. 133). If in dying Dasein is being-towards-death, then what is it precisely that Dasein is towards? Is there an intentional object in Dasein's being-towards-death? The answer cannot be simply "no", for then Dasein could be towards death even if it believed it was immortal (Llewelyn, 1983: p. 134). Hence, the object is not strictly non-empirical or non-ontic. But the intentional object is not ontic death either since Heidegger rules out any link to empirical beliefs. The problem is therefore how Dasein can ontologically relate to death without losing its intentional object (Llewelyn, 1983: pp. 133-134).

Llewelyn finds his solution in the specific characterisation of Dasein. Since Dasein is, in its very Being, an issue for itself, Dasein is necessarily a being-towards-death (BT: 276-7; SZ: 233-4). According to Llewelyn, Dasein can adopt an authentic or an inauthentic way of being towards death, each one of them related to its own intentional object (Llewelyn, 1983: pp. 134-135). Inauthentically, the object of Dasein's being-towards-death is the ontic demise that Dasein expects. Authentically, the object of Dasein's being-towards-death is a non-object, a non-thing. According to Llewelyn, Dasein relates ontologically to death when it exists authentically towards death, i.e., facing the possibility of there being nothing (Llewelyn, 1983: pp. 135-136; BT: 236-8, 305-8, 354; SZ: 191-3, 261-3, 306).

\subsection{The Intertwining between Ontic and Ontological Possibilities}

Although Llewelyn's correction of Edwards analysis is convincing-in that he provides, in line with Heidegger's claim, an ontological account of being-towards-death-he does not entirely do justice to Edward's interpretation. Llewelyn asserts that Edwards interprets Heidegger as denying ontic assertions about death (Llewelyn, 1983: p. 131). But Edwards does not do so. When Heidegger asserts that death is not an actuality, Edwards does not believe him to deny death but to describe it. What Heidegger means, Edwards writes, is that death "is a total absence, that it does not have any 'positive content' which can be 'pictured', that it is not a 'state'” (Edwards, 1975: p. 560). Edwards' point is thus not that Heidegger denies actual death but that he superfluously describes it as the absence of all states, or in other words, as "total absence” (Edwards, 1975: p. 557).

Edwards' account of the intentional "object" of being-towards-death as "total absence" and Llewelyn's account of it as "there being nothing" have a good deal of similarity to Heidegger's description of authentic being-towards-death in which the "schlechthinnige Nichtigkeit" of Dasein is revealed (BT: 354; SZ: 306). As Edwards translates "schlechthinnige Nichtigkeit" as "total nothingness", we may conclude that both Edwards" and Llewelyn's analyses come down to an intentional "object" of being-towards-death in terms of nothingness. That Edwards labels this analysis as altogether superfluous leaves unimpended that he agrees with Llewelyn that Dasein, in authentically being-towards-death, is intended to nothingness and that this intention is a possibility of Dasein to understand its own Being (Edwards, 1975: pp. 557, 560-562).

The question therefore is how Edwards' and Llewelyn's accounts of nothingness relate to each other. Obviously, Edwards understands nothingness ontically as the actuality of Dasein's end, i.e., the total extinction in which all experiences and behaviour are absent (Edwards, 1975: pp. 562-566). Llewelyn, in contrast, understands nothingness ontologically as a possibility of Dasein "to be wholly itself, a finite whole because it exists endingly” (Llewelyn, 1983: p. 135). But this difference loses its strength when we see that both the ontic and the ontological understanding of nothingness lack any further description or elaboration. Edwards' and Llewelyn's interpretations of towards what Dasein is in being-towards-death therefore appear to converge on the objectlessness of the nothing. 
Our analysis thus far implies that the ontic and the ontological account of being-towards-death can be distinguished but not be separated from each other. That is to say, the ontological possibility of Dasein to understand its own Being through death can be distinguished from the ontic possibility of actual death. But the meaning of nothingness - as the intentional “object” through which Dasein comes to self-disclosure-cannot be understood separately from Dasein's not-being-there-anymore. Llewelyn’s ontological analysis of Dasein as a being-towards-death only makes sense against the ontic background of death as “the absence of all states”. Heidegger's analysis therefore implies a conception of death in which the ontic and the ontological meaning of death are intertwined.

\section{Death Is a Way to Be}

\subsection{A False Syllogism in Ontic Terms}

A second well-known assertion in Heidegger's analysis is that “death is a way to be” [Der Tod ist eine Weise zu sein] (BT: 289; SZ: 245). Various authors reject the meaningfulness of this assertion on the basis of, again, an alleged shift in the meaning of possibility. This shift in meaning, here with regard to the characterisation of death in terms of Dasein, is most explicitly articulated by Philipse, who claims that Heidegger's assertion is based on a "baffling syllogism" (Philipse, 1998: 362ff). ${ }^{6}$

The syllogism to which Philipse refers, has as its major premise that "Dasein is its possibilities" (BT: 183; SZ: 143), while the minor premise asserts that "death is a possibility of Dasein" (BT: 294; SZ: 250). The resulting conclusion is therefore that "Dasein is its death, or, in other words, death is a mode of existing” (Philipse, 1998: p. 362).

Syllogisms are valid on the condition that the middle term has the same meaning in both premisses. In Heidegger's analysis, Philipse argues, there is no such shared meaning. Following Edwards, Philipse claims that "possibility” in the premise "Dasein is its possibilities” refers to Dasein's capability of choosing, whereas "possibility" in the premise "death is a possibility of Dasein" refers to the impossibility of any future life (Philipse, 1998: pp. 362-363, 365, 368). This shift in the meaning of "possibility" implies a shift in the meaning of the middle term. Hence, Philipse argues, the conclusion that death is a mode of existence does not follow (Philipse, 1998: p. 363).

To show the implications of Heidegger's error, Philipse places the three meanings of possibility-as capability of choosing, impossibility of any future life and mode of existing - in the context of Heidegger's followers who have claimed that death is "the culmination of life, a golden opportunity, the crown of our existence" (Philipse, 1998: p. 356). Once all these meanings are applied to Heidegger's assertion that "death is a mode of existence”, it turns out that the pure possibility of death is a "golden opportunity" for Dasein precisely because it destroys its possibility of choosing and therefore nullifies the possibility of any future life (Philipse, 1998: pp. 356-358). This is, Philipse stresses, a “perverse” assertion (Philipse, 1998: pp. 356-357, 363).

According to Philipse, Heidegger's strange mix of meanings of possibility often remains unnoticed. Once these meanings are revealed, the doctrine that "death is a mode of existence" appears to be "utterly incoherent and confused” (Philipse, 1998: pp. 368, 374).

\subsection{A Valid Syllogism in Ontological Terms}

Philipse's critique of the assertion that "death is a way to be” has received limited attention (Carman, 2001; Philipse, 2001). A reason for this may be that a different version of the syllogism had already been extensively explored in a more positive way by Blattner (1994).

Blattner formulates the syllogism regarding "death as a way to be” as follows. The major premise states that "Death is a possibility for Dasein", the minor premise that "Dasein's possibilities are possible ways to be Dasein”, which lead to the conclusion that “death is a possible way to be Dasein” (Blattner, 1994: p. 50). Blattner denies that the syllogism represents a shift in the meaning of possibility. He argues that Heidegger would

\footnotetext{
${ }^{6}$ Prima facie, it may appear strange to analyse Heidegger's conception of death in terms of a syllogism. After all, Heidegger conducts a phenomenological analysis, not a logical one. Moreover, Heidegger is well aware that his "prose frequently violates the grammatical conventions of logical discourse", suggesting that "traditional logic is of no positive guidance in asking the question of being” (Carman, 2001: pp. 567-568; WM: 108, 116). On the other hand, as Macquarrie and Robinson observe, on some occasions Heidegger uses the verb "erschliessen", which means not only to "disclose" but also to "infer" or "conclude" in the sense in which one "infers" a conclusion from premisses (BT: $105 \mathrm{n} 1,362$ ). Philipse's syllogism may therefore lead to additional information insofar as it is in line with the outcome of Heidegger's phenomenological approach (see Philipse, 2001: p. 583; Heidegger, 1927e: pp. 42, 178).
} 
have noticed the apparent contradiction that "Death is a possible way to be Dasein, one in which Dasein is not able to be" and stresses that in Heidegger's analysis "possibility" is meant as an existential possibility, which is "the ontological determination of Dasein” (BT: 183; SZ: 143-4; Blattner, 1994: p. 51).

To settle the contradiction, Blattner appeals to Heidegger's distinction between demise [ableben], which is Dasein's particular way of perishing in which Being is an issue for Dasein (BT: 182, 291; SZ: 143, 247), and death [Tod] as a way to be (BT: 289; SZ: 245). The possibility of death, Blattner argues, cannot be understood as a possibility for Dasein to understand its demise, whether it is authentically or inauthentically confronted (Blattner, 1994: pp. 53, 56-57). After all, in such a confrontation Dasein would "be treated as something presentat-hand or ready-to-hand”, which implies an ontic understanding of Dasein (BT: 289; SZ: 245; Blattner, 1994: pp. 51-52). ${ }^{7}$ The question for Blattner thus is how the contradiction - that "Death is a way to be Dasein, one in which Dasein is not able to be" - can be resolved without understanding death in terms of demise.

Blattner finds his solution in a distinction between a thin and a thick sense of Dasein's Being (Blattner, 1994: p. 58). In the thin sense, Dasein is as far as Dasein's Being is an issue for Dasein. In the thick sense, Dasein is able-to-be someone by throwing itself into possibilities (Blattner, 1994: pp. 58, 62). This distinction enables Blattner to interpret Heidegger's conception of death as an existential death in which everything becomes indifferent to Dasein. That is, Dasein still is in the thin sense (in which Dasein is at issue for Dasein), but is no longer able-to-be in the thick sense (in which Dasein is able to throw itself into possibilities). Hence, Blattner's double ontological interpretation results in an existential understanding of death as a way to be Dasein in which Dasein is an issue for itself but is unable to project itself into some way to be Dasein (Blattner, 1994: pp. 62-63).

\subsection{An Ontic-Ontological and Multi-Layered Understanding of Possibility}

At first sight, Blattner shows, retrospectively, that Philipse misinterprets the syllogism about death as a way to be. However, Blattner does not solve the entire issue. That is to say, he does not elaborate the stricking similarity between his own formulation of death as the "absence of ability to be" and Philipse's formulation of it as the "absence of all states", which Philipse further describes as "the impossibility of any future life" (Philipse, 1998: pp. 362-363, 365, 368). Does this mean that Blatterner’s interpretation is, in the end, ontic-ontological rather than ontological?

That this is indeed the case can be shown by means of Blattner's interpretation of "Dasein's end". Since Dasein is characterised in terms of ability, Blattner asserts that the "end" of Dasein is not a stopping of Dasein but a limiting of Dasein's ability. ${ }^{8}$ Hence, death does not reveal the stopping of Dasein but the limiting of its ability-to-be, which is ontological (Blattner, 1994: 63-67). However, Blattner then further explains: it is "a limit-situation [...] in which one confronts" "the limits of Dasein's ability-to-be", thereby seeking to "respond to" the issue of "one's being", but in which Dasein is unable to "exercise its ability to determine who it is" (Blattner, 1994: p. 67, our italics). Blattner thus steps over from an ontological vocabulary of "Dasein's end" to an ontic vocabulary of dealing with death as a situation in which Dasein is unable to be "someone in particular" (Blattner, 1994: p. 62).

The fact that Blattner describes the "limit-situation" of death in ontic-ontological terms has implications for the syllogism presented. That is to say, although Blattner clarifies the ontological "absence of ability to be" as a "limiting of Dasein's ability", the limiting of this ability itself is defined by an ontic setting in which all states are absent. We therefore may conclude that Blattner's ontological account of death as the "absence of ability to be" relies on an ontic understanding of death as the "absence of all states".

Likewise our analysis of Edwards and Llewelyn illuminates the ontic-ontological character of "Dasein as a being-towards-death", our analysis of Philipse and Blattner lays bare the ontic-ontological character of "death as

\footnotetext{
${ }^{7}$ Dasein differs from both something present-at-hand [das Vorhandene] and something ready-to-hand [das Zuhandene]. Something presentat-hand refers to entities that function in their identity independently from Dasein's plans and practices and, as such, occur to Dasein. Something ready-to-hand refers to entities that depend in their identity on Dasein's plans and practices and as such are available to Dasein. Hence, present-at-hand refers to the occurrent, whereas ready-to-hand refers to the available (see Blattner, 1994: pp. 51-52).

${ }^{8}$ Blattner bases his assertion on Heidegger’s analysis of "stopping” [Aufhören] in §48 of Sein und Zeit. He argues that Heidegger rejects the meaning of stopping since it is "parasitic upon the ontology of the occurrent or available” (Blattner, 1994: p. 65). Since Dasein's ability to be is not available, it does not stop. Instead, on the basis of Heidegger's footnote on Jaspers notion of "limit-situation" [Grenzsituation] (BT: 495 n.vi; SZ: 249 n.1), Blattner argues that abilities can be prevented from being exercised. For example, "in the absence of light, the ability to see is non-existent". In this way, "utter darkness is a limit-situation for sight". Likewise, Blattner argues, "Death is the limit-situation that defines the limits of Dasein's ability-to-be”. The end of Dasein does then not refer to a stopping but to a limitation of Dasein, which ontologically precedes the stopping of the occurrent or available (Blattner, 1994: pp. 65-67).
} 
a way to be Dasein”. That Heidegger's analysis implies-ultimately-an ontic-ontological framework for the understanding of death should not surprise, however. After all, Heidegger himself writes that the ontological analysis, in grounding all existential analysis, relates to the ontic understanding of reality (BT: 360-1; SZ: 312-3). With regard to death this means that the ontic meanings of death are consonant with the existential analysis of death (BT: 293; SZ: 248).

Since both ontic and ontological aspects appear in Heidegger's analysis of death, the evaluation of the various meanings should not only be based on their interrelated coherence but also on the explanatory force of each separate meaning to provide insight into the complex phenomenon of death. We therefore suggest that Heidegger's analysis provides an ontic-ontological and multilayered framework for the understanding of death in terms of possibility.

\section{Death Is the "Possibility of Impossibility" of Dasein}

\subsection{Death Is an Impossible Possibility}

A third famous assertion of Heidegger is that "death is the possibility of the absolute impossibility of Dasein" (BT: 294; SZ: 250). Various authors have rejected that the conjunction between "possibility” and "impossibility" can be interpreted in a coherent and meaningful way. Among these authors Derrida presents the most thorough criticism of the possibility of an impossibility.

Regarding the analysis of death, Derrida argues that two meanings of possibility co-exist in “die Möglichkeit”. On the one hand, the possibility of death implies "the imminence of the future" as something "that can always happen at any instant", i.e. it is something that we expect. On the other hand, the possibility of death implies "the possible as that of which I am capable” (Derrida, 1993: p. 62). These different meanings imply that Dasein is incorrectly understood as a substantial object, whereas the essence of Dasein "is precisely the possibility, the being-possible (das Möglichsein)” of Dasein (Derrida, 1993: p. 63). Therefore, what should be the theme of the existential analysis of Dasein’s death is not Möglichkeit but Möglichsein, which is the "being-possible” or “potentiality” or “ability” of Dasein (Derrida, 1993: pp. 62-63, our italics).

Derrida stresses that this "being-possible" of death is not just a possibility like other possibilities: death is possibility "par excellence". That is, death exceeds the "being-possible" as the being proper to Dasein, for it “exemplarily guides the whole existential analysis” (Derrida, 1993: p. 63). We therefore have to distinguish between two types of ontological statements in Heidegger's analysis. The first series of statements are assertions that characterize death in terms of Dasein's most proper possibility. From this perspective, being-possible [Möglichsein] is proper to Dasein as entity, and death is considered "the most proper possibility of this possibility” (Derrida, 1993: p. 64). The second series of statements are what Derrida calls "aporetic supplements of the first series" (Derrida, 1993: p. 67). That is to say, the "impossibility" adds an impossible complement to the possibility of death: death, as the most proper possibility for Dasein, is at the very same time "the possibility of an impossibility” (Derrida, 1993: p. 68). The supplement is aporetic because, according to Derrida, we can neither think nor testify to this paradox.

The aporetic supplement has severe implications for Heidegger's existential analysis. Since death, in Derrida's words, "guides the whole existential analysis", death is not just a paradox of a "possibility of impossibility" but, more comprehensively, it is "possibility as impossibility” (Derrida, 1993: pp. 70-71). Hence, it is precisely the coincidence of possibility and impossibility that, as such, gives access to the meaning of dying, for it is in dying that Dasein is “as if in accord with (Verstehen) its own death” (Derrida, 1993: p. 71; BT: 307; SZ: 262). But, Derrida wonders, how can the "possibility as impossibility” appear as such without immediately disappearing” (Derrida, 1993: p. 71)? For Derrida this is not possible because the appearance of a possibility as impossibility annihilates its own possibility at the very same time. As a consequence, death-as Dasein's most proper possibility - becomes "the most improper possibility and the most ex-propriating, the most inauthenticating one” (Derrida, 1993: p. 77).

\subsection{Death Is a Possible Impossibility}

Derrida's analysis is criticised by Thomson. He argues that Derrida incorrectly understands Möglichsein as “ability to be”. In order to grasp correctly the meaning of possibility as an existential possibility, we must distinguish between being-possible, which corresponds to Möglichsein, and ability-to-be, which corresponds to 
Seinkönnen. Taking this distinction into account, we can see that "being-possible" refers to "the constant charting of 'life-options'”, or "choices that matter”, "in which we are always already immersed” (Thomson, 1999: pp. 31-32). Ability-to-be, on the other hand, refers to Dasein's existence through these options. Hence, whereas Dasein understands its being in terms of its possibilities-to-be [Möglichsein], these possibilities enable us in a general sense to be what we are [Seinkönnen] (Thomson, 1999: p. 32; BT: 183; SZ: 143-144).

Derrida thus makes, according to Thomson, a "semantic glissement" in which he substitutes Möglichsein for Seinkönnen. This allows Derrida to understand Heidegger's existential possibility as "capability", i.e. the power or potentiality that Dasein has, instead of "ability", i.e. that what enables us to be what we are. Once we see Derrida's error, Thomson asserts, the alleged shift in the meaning of possibility [Möglichkeit]—from "expected future" to "capability" — disappears. Instead, "the possibility of the impossibility" turns out to be a coherent and unified construction in which the possibility as "expected future" refers precisely to the ontological impossibility of Dasein's “ability-to-be” [Seinkönnen] (Thomson, 1999: p. 33). ${ }^{9}$

Thomson's analysis of "the possibility of impossibility" has serious implications for his understanding of death. If the essence of the existential analysis is not Dasein's "being-possible” [Möglichsein] but Dasein's "ability-to-be" [Seinkönnen], then death is not a particular possibility for Dasein "to be" but rather "the universalized "can be" of Dasein" (Kisiel in Thomson, 1999: p. 32, our italics). Hence, according to Thomson, the possibility of death is that which makes the future matter; it "opens the horizon within which we "press-into" the possibilities which in turn constitute us” (Thomson, 1999: p. 33). In summary: death is proper to Dasein because it appears to Dasein as "the horizon within which all embodied possibilities unfold" (Thomson, 1999: p. 33).

\subsection{Death Constitutes Dasein as a Transcendent Being}

Thomson's correction of Derrida's is convincing as it provides a coherent explanation of Heidegger's claim that death is the "possibility of impossibility". His analysis, however, does not entirely do justice to Derrida's conception of death as such (Thomson, 1999: p. 39 n16, 40 n30, 41 n42). That is to say, Derrida attributes to Heidegger an untenable reliance on the impossible experience of death as such, which-Thomson suggests-is in Derrida's account an ontic event (Thomson, 1999: p. 34). But Derrida's understanding of "death as such" is more complex than that. To examine the relevance of what Derrida has to say, we must briefly return to his analysis of the aporia of "death as such".

According to Derrida, it is due to the self-annihilating structure of "the possibility as impossibility", that "death as such" cannot appear to Dasein. What Derrida has in mind here is not ontic death as such—as Thomson suggests—but the annihilation of the "as such" of the possibility itself. Thus, Derrida writes: "The impossibility that is possible for Dasein is [...] that precisely what is possible becomes impossible, from then on no longer appearing as such" (Derrida, 1993: p. 75). Or with more emphasis, death is the "disappearance, the end, the annihilation of the as such, of the possibility of the relation to the phenomenon" (Derrida, 1993: p. 75; BT: 307; SZ: 262). The wordings "possible for Dasein" and the "disappearance [...] of the relation to the phenomenon" (our italics) show what Derrida has in mind: not ontic death but the disappearance of the possibility to which Dasein relates in its Being.

Hence, it turns out that Derrida and Thomson both have an ontological interpretation of Heidegger's understanding of death. For Thomson, death is ontologically proper to Dasein in the sense that the possibility of death appears to Dasein as the horizon for all other possibilities. For Derrida, death is improper to Dasein in the sense that Dasein cannot relate understandingly to the aporetic structure of death. Derrida's ontological interpretation of the "as such", however, shows that this improperness of death has two sides: death—as aporia—is most improper to Dasein, but precisely this improperness is ontologically most proper to Dasein.

Whereas in Aporia (1993) Derrida does not distinguish between death as most proper and as most improper to Dasein, in The gift of death (1995) he seems to take up the challenge to resolve the issue. In a reflection on Heidegger's claim that "Dying is something that every Dasein itself must take upon itself at the time" (BT: 284; SZ: 240), Derrida suggests that Heidegger's analysis implies that man himself must take possession of death. Death is not mine indeed but, as such, must be appropriated (Derrida, 1995: 44 ff; Ettema, 2013: pp. 579-580,

\footnotetext{
${ }^{9}$ Heidegger’s preference of Seinkönnen [ability-to-be] over Möglichsein [being-possible] might also be clarified on the basis of the given that Heidegger provides an ontological rather than logical analysis of death. Because Seinkönnen relates more to ontological modalities and Möglichsein more to logical modalities, Heidegger might have chosen Seinkönnen as the more fitting notion to Dasein's Being in terms of possibility. This clarification is shored up by the interrelatedness between Möglichsein and Seinkönnen. That is to say, Seinkönnen and Möglichsein imply each other since to have potentiality [Möglichsein] implies to be potential [Seinkönnen] and visa versa.
} 


\section{2-584).}

The issue of appropriation suggests that Dasein transcends through the possibility of death. To be clear, the transcendent is for Heidegger not some metaphysical domain "toward which I step over" but "that which oversteps as such" (Heidegger, 1927e: p. 299). As such, transcendence is constitutive for Dasein's selfness [Die Transzendenz konstituiert die Selbstheit] (Heidegger, 1929: p. 138). Although Heidegger does not elaborate on the relationship between transcendence and death, he asserts that Dasein is "the transcending being" (Heidegger, 1927e: p. 300; Raffoul, 2008: p. 289) and that death is "the highest and outermost testimony of Being" [das höchste und äußerste Zeugnis des Seyns] (Heidegger, 1936/1938: p. 284). These wordings suggest that death constitutes Dasein as a transcendent Being, i.e. a Being which is able to appropriate death.

\section{Death Is an ausgezeignete Possibility of Dasein}

\subsection{The Uncovering Force of Death}

Heidegger's complex analysis of death as a possibility culminates in the characterisation of death as an ausgezeignete Möglichkeit of Dasein (SZ: 248, 251). That it is not easy to understand what Heidegger means with "ausgezeignet-e Möglichkeit”, appears from the range of translations of ausgezeignete, varying from "distinctive” (Heidegger, 1927b: pp. 292, 295) to "eminent” (Heidegger, 1927c: pp. 231-232), "greatest” (Kovacs, 2002: p. 210), "splendid" (Edwards, 1975: p. 551) and even "excellent” (Philipse, 1998: p. 356). The assertion that death is an ausgezeignete Möglichkeit therefore adds new questions to our analysis thus far: What is the ausgezeignete possibility of death precisely about? How "distinctive" is this possibility of Dasein actually? And how does it relate to the transcendent Being of Dasein?

Basically, what makes the possibility of death distinctive is that it reveals authentic existence (BT: 307; SZ: 263). It is widely accepted, however, that Heidegger's account of authenticity—and its relationship to inauthenticity-is not straightforward (Mulhall, 1996: pp. 69-70). One of the interpreters who accounts for various interpretations of (in) authenticity is Carel $(2007,2006)$. She has developed an integrative model in which authenticity and inauthenticity are understood as conflicting, complementary and mutually dependent modes of existence (Carel, 2006: pp. 106, 108-109). Since we hold an ontic-ontological, multilayered and transcendent understanding of "possibility", we take her analysis as point of departure for our analysis of the relationship between the possibility of death and authenticity.

To specify what authentic engagement to death is about, Carel refers to Heidegger's distinction between a non-genuine [unecht] and a genuine [echt] authentic mode of relating to death (BT: 186; SZ: 146). In the objectless anxiety for death, Dasein relates authentically but non-genuinely to its own end: authentically because it "discloses the world as a whole"; non-genuinely because it makes Dasein unable to be a participant in its world and projects (Carel, 2007: p. 545; 2006: pp. 80, 105; BT: 231-4; SZ: 187-9). But Dasein cannot hold on to this situation and must "return to being in the world" (Carel, 2006: p. 87). One of the possibilities is then that non-genuine authenticity is followed by genuine authenticity, which is expressed in Dasein's "expansion of its ability to view itself and its world and to respond to this new perspicuity" (Carel, 2006: p. 107; see also: 2007: pp. 545, 547; 2006: 87). ${ }^{10}$ This genuine authenticity, Carel stresses, relates to what Heidegger calls an "unshakable joy” [gerüstete Freude] (Carel, 2006: p. 111; BT: 358; SZ: 310).

\subsection{Death Is an "Excellent" Possibility of Dasein}

As Heidegger does not elaborate upon the issue of "unshakable joy", the question is whether ausgezeignete Möglichkeit should be translated in a profuse term as splendid or excellent possibility, i.e.: is death an "excellent" possibility for Dasein? Carel does not think so. She strongly rejects a translation as "excellent" and holds to the neutral translation of “distinctive” (Carel, 2007: pp. 550-551). In order to examine Carel’s position, we must return for a moment to her interpretation of Blattner, who functions as a stepping stone for Carel's view on the meaning of death as a possibility.

Carel claims that Blattner understands death one-sidedly in terms of "finitude of possibilities", thereby ne-

\footnotetext{
${ }^{10}$ Whether non-genuine authenticity is followed by genuine authenticity or not, depends, in Carel's view, on Dasein’s resoluteness [Entschlossenheit]. Carel briefly explores the meaning of resoluteness as “openness” in contrast to an "expression” of Dasein's “will or choice” (Carel, 2007: p. 545; 2006: p. 107). Russon does so with regard to the openness to value and meaning (Russon, 2008: p. 100). Unfortunately, it goes beyond the scope of this paper to discuss the issue of resoluteness.
} 
glecting the ontological finite structure of Dasein itself. To correct this error, she introduces the notion of "temporal finitude” (Carel, 2007: pp. 542, 547; 2006: p. 83). Carel thus arrives at a double ontological characterisation of Dasein's finite structure: 1) finitude of possibilities, designating the "ever-present threat to Dasein's meaningful dealing with the world"; and 2) temporal finitude, pointing out that Dasein is a constant projection towards its ever impending annihilation (Carel, 2007: p. 547; 2006: p. 83).

According to Carel, finitude of possibility (being-towards-death) and temporal finitude (being-towards-theend) are both essential and interrelated components of the transition to authenticity (Carel, 2006: p. 83). In this transition, both types of finitude "define the boundaries of meaningful experience". Finitude of possibilities does so with regard to "the helplessness and limitation on what is achievable within life" (Carel, 2006: p. 83, our italics). Temporal finitude, on the other hand, defines the boundary of meaningful experience with regard to the end of Dasein's future itself (Carel, 2006: p. 83). But whereas Carel extensively elaborates the meaning of finitude of possibilities in terms of non-genuine and genuine authenticity, she just characterises temporal finitude as an “ungraspable aspect” of Dasein’s existence, without further exploration (Carel, 2006: p. 83).

The limited exploration of temporal finitude allows Carel to present a more neutral model of death then is justified. More neutral, because her overall evaluation —in which the anxiety of non-genuine authenticity is balanced by the joy [Freude] of genuine authenticity—obscures that genuine authenticity itself may be characterised as an "excellent" possibility indeed. However, temporal finitude, in turn, reveals that this excellent possibility of death is incessantly beset by Dasein's movement towards annihilation. The excellent possibility of death must therefore be understood as just one of Dasein's various coexisting, concurrent and conflicting modes of existence.

\subsection{Transcendence: Non-Genuine, Genuine and Deconstructive Authenticity}

Considering that temporal finitude plays a central role in Carel's interpretation of death as a possibility, we may now wonder how temporal finitude relates to death as a transcendent possibility for Dasein. Although Heidegger does not explicitly elaborate on the relationship between death and transcendence, he emphasises that "what exists as a self can do so only as a transcendent being" (Heidegger, 1927e: p. 300) and that "Dasein's transcendence" is made possible by "temporality" (BT: 415; SZ: 364). Since temporality relates to non-genuine and genuine authenticity as well as to Dasein's movement towards annihilation—and this is the point we wish to make - we should distinguish between various aspects of transcendence. ${ }^{11}$

A first aspect of transcendence corresponds to the possibility of death as Dasein's non-genuine authentic comportment towards death. That is, in being-towards-death, Dasein becomes aware of its finitude of possibilities. The resulting meaninglessness is experienced in anxiety [Angst], which throws Dasein back on itself and uncovers the unity of Dasein and its being-in-the-world. Hence, by understanding the wholeness of its Being, Dasein transcends its own being. As such, Dasein transcends not what it is, but what it is not (BT: 185-6, 301-2, 310; SZ: 145, 257-8, 265). It is in this sense that Dasein becomes what it is: it transforms itself from a being for which its Being is at stake, to a being that stands, in anxiety, open to the Being-there of itself.

A second aspect of transcendence corresponds to the possibility of death as Dasein's genuine authentic comportment towards death. The anxiety in which Dasein is aware of its wholeness nullifies the possibility to be in the Blattner-Thomson sense. Dasein must therefore turn away from anxiety and return to its being-in-the world in which it exists. That is to say, Dasein exists as a being-in-the-world and, as such, it "rediscovers its world and projects as necessary to its existence" (Carel, 2006: p. 87). Hence, Dasein rediscovers not only that it is but also that is has to be [Dass es ist und zu sein hat] (BT: 173; SZ: 134). This rediscovering of its genuine authenticity in which Dasein can testify to oneself, goes together, Heidegger hints, with an "unshakable joy" [gerüstete Freude] (BT: 358; SZ: 310).

A third aspect of transcendence corresponds to the possibility of death as-what we will call—Dasein's deconstructive authentic comportment towards death. That is to say, the possibility of death not only uncovers Dasein's finitude of possibilities but also its temporal finitude. Dasein thus not only stands open to non-genuine and genuine authentic Being-there but also to its no-longer-Dasein [Nichtmehr-dasein] (BT: 281; SZ: 237). The

\footnotetext{
${ }^{11}$ That we should distinguish between different aspects of death as a transcendent possibility for Dasein is shored up by Heidegger when he writes: "What exists as a self can do so only as a transcendent Being. This selfhood, founded on transcendence, the possible toward-itself and out-from-itself, is the presupposition for the way the Dasein factically has various possibilities of Being its own and of losing itself" (Heidegger, 1927e: p. 300; Heidegger, 1927d: p. 425-426).
} 
analysis of death as a transcendent possibility for Dasein must therefore be completed with an analysis of Dasein's authentic comportment towards death as annihilation. As in this comportment Dasein relates authentically to the nullification of its authenticity, we call this third aspect of transcendence, deconstructive [Abbauende] authenticity. $^{12}$

The issue of deconstructive authenticity reveals a profound insight with regard to the meaning of death. Whereas Heidegger bases his phenomenological analysis on Dasein's Being, the understanding of Dasein's annihilation grounds ultimately in the understanding of not-Being-or more precisely: in the understanding of the possibility of “notness” (BT: 331-2; SZ: 285-6). Dasein’s deconstructive authenticity, in which Dasein relates authentically to its own ontological annihilation, therefore remains necessarily outside Heidegger's analysis of death (BT: 332; SZ: 286). As a consequence, whereas non-genuine and genuine authenticity relate to anxiety and joy respectively, deconstructive authenticity remains_in Heidegger's analysis_necessarily indefinite. Deconstructive authenticity — as being one aspect of death as a possibility — therefore implies that Dasein is, to a certain extent, free to depict the meaning of its own death. ${ }^{13}$

\section{Conclusions}

During the last three decades, the meaning of Heidegger's conception of death as a possibility has been mainly debated along the lines of ontic versus ontological interpretations. Although the debate has revealed many aspects of Heidegger's conception of death as a possibility, little progress has been made towards a hypothesis which integrates these insights. In contrast to the interpretations here examined, we have argued that Heidegger's analysis of death in terms of possibility must be understood as an ontic-ontological and multi-layered framework for the understanding of the phenomenon of death. These various meanings of death as a possibility can be distinguished but not separated from each other and must be understood as coexisting, concurrent and sometimes conflicting modes of existence.

The main meanings of death as a possibility that appear in our analysis are absence of all states (Edwards), impossibility of any future life (Philipse), nothingness (Edwards, Llewelyn), anticipated demise in inauthentic being-towards-death (Llewelyn), the non-object in authentic being-towards-death (Llewelyn), a way of Being in which Dasein is an issue for itself (Blattner), a way of Being in which Dasein is its ability to be (Blattner), Dasein's most improper aporia (Derrida), the annihilation of the possibility as such (Derrida), the horizon within which all embodied possibilities unfold (Thomson), a golden opportunity (Edwards) and the annihilation of Dasein (Carel).

In addition to these meanings, we have asserted that Heidegger's analysis comprises a meaning of death as a transcendent possibility for Dasein. In this possibility Dasein comports itself authentically towards death. This authentic comportment can be distinguished into non-genuine, genuine and, what we have called, deconstructive authenticity as co-existing, concurrent and conflicting modes of existence. Finally, we have argued that in deconstructive authenticity Dasein relates authentically to its own ontological annihilation, which cannot be phenomenologically depicted. Consequently, whereas non-genuine and genuine authenticity relates to anxiety and joy respectively, deconstructive authenticity necessarily remains indefinite, thereby implying that Dasein is, to a

${ }^{12}$ It may be objected that Heidegger's analysis is based on destruction rather then deconstruction. After all, for Heidegger, all phenomenological understanding implies the destruction [Destruktion] of the historical roots of the concept concerned (Heidegger, 1927d: pp. 27-32; 1927e: pp. 20-23). Accordingly, to understand Dasein's transition to no-longer-Dasein, we have to destruct [destruiren] the historical roots of this concept itself. Heidegger stresses, however, that the negative result of Destruktion is foundational for a phenomenological construction [phänomenologische Konstruktion] of the concept (BPP: 21-3; GP: 29-31). The aim of Heidegger destruction is thus "positive; its negative function remains unexpressed and indirect” (Heidegger, 1927d: pp. 29-31; 1927e: pp. 21-23). Various authors therefore suggest that Heidegger performs, in the end, a deconstruction rather than destruction (e.g. Russon, 2008: p. 106; Mulhall, 1996: pp. 22, 27; Faulconer, 1998; Janicaud, 1995: pp. 3-4; Derrida, 1987: p. 388; Sallis, 1984: p. 601). We therefore call Dasein’s authentic comportment towards death as no longer Dasein, deconstructive authenticity. In doing so, Heidegger's specific understanding of Destruktion and its function in fundamental ontology should be taken into account. For the meaning of deconstructive authenticity this implies that Dasein's authentic comportment towards death as no-longer-Dasein, refers to an existential approach in which Dasein relates understandingly to the annihilation of its own end.

${ }^{13}$ Prima facie, the suggestion that Dasein is free to depict the meaning of its own death goes beyond Heidegger's analysis of death (BT: 292; SZ: 247-8). That is to say, Heidegger is very clear in his claim that the ontological analysis of death "does not imply any ontical decision whether 'after death' still another Being is possible” (BT: 292; SZ: 247). However, the issue is not if after death another Being is possible, but how the unshakable joy of genuine authenticity relates to its very own nullification. Although Heidegger describes this unshakable joy in terms of Dasein's freeing from the events of the world, he immediately adds that "the analysis of these moods would transgress the limits'of fundamental ontology” (BT: 358; SZ: 310). The ontological limits of Heidegger's analysis of death therefore imply an unconditioned freedom with regard to the ontic domain of death. It is in this sense that the indefiniteness of deconstructive authenticity implies that Dasein is, to a certain extent, free to depict the meaning of its own death. Unfortunately, it goes beyond the scope of this paper to go deeper into the question what the ontic depiction of death may look like. 
certain extent, free to depict the meaning of its own death.

Taking into account that we all have to die once, Heidegger's analysis of death as a possibility only makes sense against the background of how we deal with this inevitable fact of human existence. According to Heidegger, death is not only an ontological phenomenon but it is also ontically distinctively impending [ein ausgezeigneter Bevorstand]. Death is therefore something that "Dasein itself has to take over [zu übernehmen] in every case" (BT: 294; SZ: 250). If this interpretation is—-to a more or lesser extent—correct, it is undoubtedly a valuable enterprise to further elaborate on an ontic-ontological, multilayered and transcendent understanding of Heidegger's analysis of death and, from there, to apply the richness of his analysis to the event of dying.

\section{References}

Blattner, W. D. (1994). The Concept of Death in Being and Time. Man and World, 27, 49-70. http://dx.doi.org/10.1007/BF01279040

Carel, H. (2006). Life and Death in Freud and Heidegger. Amsterdam and New York: Rodopi.

Carel, H. (2007). Temporal Finitude and Finitude of Possibility: The Double Meaning of Death in Being and Time. International Journal of Philosophical Studies, 15, 541-556. http://dx.doi.org/10.1080/09672550701602916

Carman, T. (2001). On Making Sense (and Nonsense) of Heidegger. Philosophy and Phenomenological Research, 63, 561572. http://dx.doi.org/10.1111/j.1933-1592.2001.tb00125.x

Dastur, F. (1996). Death: An Essay on Finitude (Translated by J. Llewelyn). London: Athlone Press.

Derrida, J. (1987). Psyché. Inventions de l'autre. Paris: Éditions Galilée.

Derrida, J. (1993). Aporias. Stanford: Stanford University Press.

Derrida, J. (1995). The Gift of Death. Chicago, IL: University of Chicago Press.

Edwards, P. (1975). Heidegger and Death as "Possibility”. Mind, 84, 548-566. http://dx.doi.org/10.1093/mind/LXXXIV.1.548

Ettema, E. J. (2013). Death: “Nothing” Gives Insight. Medicine, Health Care and Philosophy, 16, 575-585. http://dx.doi.org/10.1007/s11019-012-9440-6

Faulconer, J. E. (1998). Deconstruction. http://www.ideayayinevi.com/okumalar/faulconer/deconstruction.htm

Halteman, M. C. (2007). Book Review of Paul Edwards, “Heidegger’s Confusions”. Philosophical Review, 116, $310-313$.

Heidegger, M. (1927a). Sein und Zeit. Tübingen: Max Niemeyer Verlag, 2001.

Heidegger, M. (1927b). Being and Time (Translated by J. Macquarrie \& E. Robinson). New York: Harper \& Row, 2008.

Heidegger, M. (1927c). Being and Time (A Translation of Sein und Zeit, Translated by J. Stambaugh). New York: State University Press, 1996.

Heidegger, M. (1927d). Die Grundprobleme der Phänomenologie. Gesamtausgabe, Band 24. Frankfurt am Main: Vittorio Klostermann, 1975.

Heidegger, M. (1927e). The Basic Problems of Phenomenology (Translation, Introduction and Lexicon by A. Hofstadter). Bloomington \& Indianapolis: Indiana University Press, 1988.

Heidegger, M. (1929). Von Wesen des Grundes. Gesamtausgabe, Band 9, Wegmarken: 123-75. Frankfurt am Main: Vittorio Klostermann, 1975.

Heidegger, M. (1929/1930a). Die Grundbegriffe der Metaphysik. Welt-Endlichkeit_Einsamkeit. Gesamtausgabe, Band 29/30. Frankfurt am Main: Vittorio Klostermann, 1975.

Heidegger, M. (1929/1930b). The Fundamental Concepts of Metaphysics (Translated by W. McNeill \& N. Walker). Bloomington \& Indianapolis: Indiana University Press, 1995.

Heidegger, M. (1936/1938). Beiträge zur Philosophie (Vom Ereignis). Gesamtausgabe, Band 65. Frankfurt am Main: Vittorio Klostermann, 1975.

Heidegger, M. (1946). Brief über den Humanismus. Gesamtausgabe, Band 9, Wegmarken: 313-63. Frankfurt am Main: Vittorio Klostermann, 1975.

Husserl, E. (1929). Cartesion Meditations. An Introduction to Phenomenology (Translated by D. Cairns). Dordrecht: Kluwer Academic Publishers, 1999.

Janicaud, D. (1995). Overcoming Metaphysics? In D. Janicaud, \& J. F. Mattéi (Eds.), Heidegger Front Metaphysics to Thought (pp. 1-14). New York: State University of New York.

Kovacs, G. (2002). Postmodern Reflections on Death. Ultimate Reality and Meaning, 25, 203-213.

Llewelyn, J. (1983). The “Possibility” of Heidegger’s Death. Journal of the British Society for Phenomenology, 14, 127-138. 
Mulhall, S. (1996). Routledge Philosophy Guidebook to Heidegger and Being and Time (2nd ed.). London and New York: Routledge, 2005.

Philipse, H. (1998). Heidegger's Philosophy of Being. A Critical Interpretation. Princeton, NJ: Princeton University Press.

Philipse, H. (2001). How Are We to Interpret Heidegger's Oeuvre? A Methodological Manifesto. Philosophy and Phenomenological Research, 63, 573-586.

Raffoul, F. (2008). Derrida and the Ethics of the Impossible. Research in Phenomenology, 38, 90-110. http://dx.doi.org/10.1163/156916408X287003

Russon, J. (2008). The Self as Resolution: Heidegger, Derrida and the Intimacy of the Question of the Meaning of Being. Research in Phenomenology, 38, 90-110. http://dx.doi.org/10.1163/156916408X262820

Sallis, J. (1984). Heidegger/Derrida—Presence. The Journal of Philosophy, 81, 594-601. http://dx.doi.org/10.2307/2026261

Thomson, I. (1999). Can I Die? Derrida on Heidegger on Death. Philosophy Today, 43, 29-42. http://dx.doi.org/10.5840/philtoday199943134 